\title{
Distribution of arsenic in Sutlej River water and sediments, eastern Punjab, India: Monsoonal role
}

\author{
MS. NAVJOT KAUR AND SUSANTA PAIKARAY
}

Panjab University

Presenting Author: navjotkaur.2493@gmail.com

River basin alluvial plain of Sutlej River supports large agricultural activity in Punjab, India with frequent reports of poor water quality. A $25 \mathrm{~km}$ river stretch and its bank sediments from Rupnagar district, east Punjab were examined for water quality and arsenic (As) contents during pre- (May 2019) and post-monsoon (December 2018) seasons. Little turbid nature characterizes the Sutlej water with more alkaline nature in postmonsoon (7.74-8.22) as compared to pre-monsoon (6.60-7.29) season. Relatively greater cationic (e.g., $\mathrm{Ca}^{2+}, \mathrm{Fe}^{3+}$ ) and anionic (e.g., $\mathrm{PO}_{4}{ }^{3-}, \mathrm{SO}_{4}{ }^{2-}$ ) enrichments were observed during postmonsoon season compared to pre-monsoon. All the analysed water samples are As-enriched (up to $245 \mu \mathrm{g} \mathrm{L}^{-1}$ ) with greater enrichments during post-monsoon season. About $94 \%$ of the samples exceeded the WHO permissible limit of $10 \mu \mathrm{g} \mathrm{L}^{-1}$. Similarly, elevated As in river bank sediments is also found (up to $\sim 104 \mathrm{mg} \mathrm{Kg}^{-1}$ ) with $60 \%$ samples above the $20 \mathrm{mg} \mathrm{Kg}^{-1}$ limit (European community). Likely transport of As-rich sediments by Sutlej River is inferred from As distribution both in bank soils and river water, while local inputs from thermal and cement plant wastes are also noticed. The greater post-monsoon As enrichment and river water ionic contents is attributed to favourable monsoonal leaching relative to pre-monsoon season. The lesser As and other ionic contents during pre-monsoon can also be caused by excess river water dilution as a result of summer glacial melting at the origin of Sutlej River. Although no significant correlation of As was found with the other elements but a very poor positive correlations of As with $\mathrm{PO}_{4}{ }^{3-}$ was inferred which suggests role of phosphate fertilizers used in the agricultural fields along the river banks in mobilization of As. 